\title{
Appraisal of the preparedness of ECOWAS towards a common currency
}

\author{
Louis Sevitenyi Nkwatoh
}

Economics Department, Yobe State University, Nigeria

e-mail correspondence:sevinkwatoh@gmail.com

\begin{abstract}
This study appraised the preparedness of Economic Community of West African States (ECOWAS) towards the adoption of a common currency by analysing the degree of symmetry and sizes of identified shocks across member countries. The analysis was situated within the framework of the Optimum Currency Area (OCA) theory and the structural vector autoregressive (SVAR) model was employed on secondary data from 1975 to 2015. The findings reveal that external supply shocks across ECOWAS countries are symmetric except for Sierra Leone, while demand, supply and monetary shocks among member countries are asymmetric. The absolute relative sizes of the different shocks across member countries are high and different in sizes. This implies that ECOWAS countries are not fully prepared to adopt a common currency and the fixed exchange rate as a stabilization policy for the entire West Africa. Hence ECOWAS governments should further shift the targeted date beyond 2020 to create ample time for member countries to get fully prepared.
\end{abstract}

Keywords: monetary union, optimal currency area, symmetry of shocks, structure VAR, ECOWAS

JEL classification: F36, F42, E52, R11

\section{INTRODUCTION}

The desire to strengthen economic integration and regional stability has motivated economic blocs across the World to assess the possibilities of establishing a common market and introducing a common currency that will facilitate economic transactions. This is achievable only if a group of countries are willing to sacrifice their monetary autonomy and implement a common stabilization policy.

Inspired by the benefits of a monetary union, the ECOWAS Heads of States adopted a two-track approach to set up a common Central Bank for the entire region with the introduction of a common currency. The creation of a second monetary union called the West African Monetary Zone (WAMZ- Gambia, Ghana, Guinea, Nigeria, Liberia and Sierra Leone) in 2003 was considered as the first tract, while the rebirth of a broader monetary union that will merge the existing West African Economic and Monetary Union (WAEMU- Benin, Burkina Faso, Côte d'Ivoire, Mali, Niger, Senegal and Togo) and the newly created WAMZ is considered as the second track.

The standard framework that examines the desirability of a monetary union is premised on the Optimum Currency Area (OCA) theory introduced by Mundell (1961), extended by McKinnon (1963) and further enriched by Kenen (1969) and Ishiyama (1975) emphasizes on the symmetry of shocks that resonate across a group of countries 
contemplating to form a monetary union. Symmetric shocks are crucial because they provide information on the costs and desirability of a union's monetary policy (Tsangarides \& Qureshi, 2008; Karras, 2006; De Grauwe, 2005). Thus, countries that exhibit high co-movements in their economic activities can proceed to a monetary union because they are likely to experience similar economic shocks with less cost.

Even though the key issues enshrined in the OCA theory among other strategies have been frequently discussed by ECOWAS governments and ratified in the various Treaties, member countries still remain vulnerable to high asymmetric shocks. Tsangarides \& Qureshi, (2008) and Karras, (2006) observed that the shocks that resonate across ECOWAS countries are uncorrelated implying that the adoption of a common stabilization policy will be costly for member countries. The asymmetry of shocks across ECOWAS is due partly to the differentials in their major exports. IMF Report (2007) reveals that Nigeria is the largest Country and the greatest oil exporter in the region while prospective union members' international trade is heavily skewed towards commodity exports, thus making the terms of trade shocks highly uncorrelated across the region.

The vulnerability to asymmetric external and domestic shocks in the entire region portents a high cost of forfeiting monetary autonomy by member countries to a common Central bank, yet ECOWAS countries have expressed their desire to introduce a common currency for the entire region by the year 2020. Therefore, the main objective of this study is to appraise the preparedness of ECOWAS towards the adoption of a common currency for West Africa.

The structure of the study is as follows: Section 1 ushers in the introduction; Section 2 discusses the theoretical underpinnings as well as the empirical literature. Section 3 presents the methodology and sources of data. Section 4 presents the results and analysis, while the conclusion and recommendations are contained in Section 5.

\section{LITERATURE REVIEW}

\section{Theoretical framework}

The discourse on the costs and benefits of establishing a monetary union is rooted in the Optimum Currency Area (OCA) theory introduced in the early 1960s by Robert Mundel and further enriched by McKinnon (1963), Kenen (1969) and Ishiyama (1975). The theory proceeded from the debate on the importance of fixed versus flexible exchange rate regimes and was also motivated by the malfunctioning of the Bretton Woods System of fixed exchange rates. While Friedman (1953) emphasizes on the relative importance of the floating regime as a basic condition for free trade because it has the ability to ease the process of adjustment to external shocks, Krugman (1990) rather submits that the fixed exchange rate regime confers a degree of stability between the participants and the numéraire country (countries), as well as between the participants. Proponents of the OCA theory go beyond the two contending views, stating clearly the conditions that must be fulfilled by countries wishing to form a monetary union.

An important perquisite entry condition for an optimum currency area according to Robert Mundell is that member countries should allow the 'free movement of factors of production' (i.e. labour, wages, or capital) across the region. Mundell's (1961) submission underscores the appropriateness of a common currency predicated on the symmetry of both supply and demand shocks in a regional bloc. Thus, mobility of factors of production balances the surpluses and deficits of member countries (Alturki, 2007) and automatically stabilizes asymmetric shocks (Kochanová, 2008). In 1973, 
Robert Mundell complimented his earlier proposition, acknowledging that candidates for a monetary union should also promote 'portfolio diversification' for international risk sharing. The simple reasoning here is that countries are not hit by severe asymmetric shocks when they share portfolio diversification in capital markets (Ling, 2001) since financial capital moves much more easily than physical capital and labour (Broz, 2005 and McKinnon, 2004).

Extending the OCA theory, McKinnnon (1963) propounded that 'trade openness ' is a decisive criterion for a monetary union and not factor mobility as initially proposed by Mundel (1961). Robert McKinnon argued that economies are more likely to adopt a fixed exchange system, the moment they become more open to one another. An important criterion that adds credence to the OCA theory is a country's 'diversification of production' propounded by Kenen (1969). More diversified economies according to Kenen, are less prone to different types of shocks; provide more job opportunities and posses a high candidacy level for a monetary union. Consequently, diversification of production in a regional bloc can maintain internal stability of prices; thus, omitting the need of exchange rate as an adjustment mechanism. Kenen also underscores the need for a well coordinated fiscal and monetary policy in guaranteeing the success of monetary integration. Sheik's (2014) supporting Kenen's view submits that fiscal policy integration would allow countries of a monetary union to redistribute funds to a member country affected by an adverse country-specific disturbance thereby guaranteeing the stability of the monetary union. Ishiyama's (1975) contribution to the OCA theory cited in Broz (2005) suggests that candidate countries of common currency should possess "inflation and wage stability" as this would signal similarities in economic structure and policies. These similarities foster a more balanced current account and trade among member countries, and therefore curbs the need for nominal exchange rate adjustment (Mougani, 2014).

The key criteria for an optimum currency area advanced by Mundell (1961), McKinnon (1963) and Kenen (1969) are factor mobility, trade openness, product diversification and similarity of inflation rates and wage stability. However, Krugman (1993) and Mongelli's (2002) Tavlas (1993), Tavlas (2009), Dellas and Tavlas (2009) submit that a successful monetary integration is incumbent on the "political will and interregional compensation" schemes of member countries.

Analyzing the preparedness of ECOWAS towards a common currency is situated within the framework of the Optimum Currency Area theory because key issues ratified in various ECOWAS Treaties are enshrined in optimum currency area theory.

\section{Empirical literature review}

A plethora of studies have evaluated the viability of a currency union by identifying the degree of symmetry of shocks among a group of economies using the structural vector auto regressive (SVAR) approach, introduced by Bayoumi and Eichengreen (1992), premised on the Blanchard-Quah decomposition of shocks between supply side and demand side to operationalize the optimum currency area theory.

Based on the Blanchard-Quah framework, Bayoumi and Eichengreen (1992) explored the size of shocks and the speed of adjustment to these shocks to the results from US annual regional data from 1970 to 2008. They found that the underlying shocks are significantly more idiosyncratic across EC countries than across US regions, In another related study, Bayoumi and Eichengreen (1994) found that currency unions were feasible among clusters of regional blocs in East Asia countries, Western 
European countries, Latin American countries and North American countries including Canada and United States. Many studies across Europe have produced similar results using the SVAR: Ramos and Suriach (2004); Frenkel and Nickel (2002); Broz (2008) and Marinas (2012). Ramos and Suriach (2004) showed that shocks are more asymmetric in candidate countries than in current Euro-zone members. Similarly, Horvath and Rátfai (2004) showed that the shocks of EMU members and candidate countries wishing to join the EMU were idiosyncratic, implying that the enlargement of the EMU will require a costly process.

Many studies have ex-rayed the feasibility of the Asian and Latin American monetary unions by evaluating the degree of symmetry in macroeconomic disturbances of member countries predicated on the Blanchard and Quah methodology. Almost all the studies are unique in their conclusion suggesting that shocks among member countries were asymmetric. For instance, Sato, Zhang and McAlee (2005), Koh and Lee (2010); Ling (2001); Tang, (2006); Jeon and Zhang (2007); Huang and Guo (2006) using the SVAR, reached the conclusion that a fully-fledged currency union in the Asian region is not necessary but rather smaller sub-groupings could possibly form a monetary union. The strand of literature on Latin American (LM): Bayoumi and Eichengreen (1994), Licandro (2000), Hallwood, Marsh and Scheibe (2006), Foresti (2007), McKnight and Sánchez (2014) among others havee a unique conclusion - the formation of a LM monetary union is not feasible.

Literature on the feasibility of the Gulf Cooperation Council (GCC) monetary union using the AD-AS framework is vast. Abu-Bader and Abu-Qarn (2008) found that GCC demand shocks were asymmetric implying that they were not good candidates for a successful monetary union. Al-Turki (2007), Benbouziane, Benhabbib, and Benamaar (2010), Louis, Balli and Osman (2010) among others Alshehry and Slimane (2012), Kandil and Trabelsi (2012) and Arfa (2012), also reach a similar conclusion.

Studies in Africa that have used the AD-AS framework to analyse the viability of a monetary union among different regional sub groupings have little nuances. Buigut and Valev (2005) established that economic shocks of SADC economies were not highly correlated across the entire region, hence they may benefit from a currency union. Njoroge, Opolot, Abuka and Okello (2011) submitted that a monetary union for Common Market for Eastern and Southern Africa (COMESA) was possible but might however make member countries more vulnerable to shocks, thereby limiting the potential benefits of monetary integration. Sheikh, Zarina and Aslam (2013) and Mafusire and Brixiova (2013) in their studies concluded that macroeconomic convergence was impossible for EAC countries.

Few studies have analysed the degree of symmetry of shocks across West African States using the SVAR mode. Addison, Opoku-Afari and Kinful (2005) found very low cross country correlations of terms of trade shocks and real exchange rate shocks across WAMZ countries. Unlike Addison et al. (2005) who used the typical Blanchard and Quah (1989) model, Chuku (2012) and Onye et al. (2012) in separate studies extended the previous model to a four-shock VAR model for ECOWAS. Their results are consistent showing that the relative responses of the economies to external disturbances are highly asymmetric as well as the correlations of supply, demand and monetary shocks among the countries. They suggested that for main time, ECOWAS should not proceed with the eco, since the costs will outweigh the benefits. Their results agree with an earlier finding by Houssa (2008) who used a dynamic factor model 


\section{METHODOLOGY}

\section{Source of data}

The data sets for the analysis are extracted from various issues of the International Financial Statistics published by the IMF, World Development Indicators published by World Bank and WAMA indicators published by the West African Monetary Agency. The study covered the period 1975 to 2015 to considerably take into account all the protocols and agreements meted out by ECOWAS and also, to fully capture the behaviour of the macroeconomic variables with respect to the convergence criteria. The variables used in the study are: World oil prices (WOP) global GDP (GGDP), real gross domestic product (RGDP), real effective exchange rate (REER) and domestic prices proxied by inflation (INF). Annual data for 14 ECOWAS economies, namely Benin, Burkina Faso, Cape Verde, Cote d'Ivoire, Gambia, Ghana, Guinea, Guinea-Bissau, Mali, Niger, Nigeria, Senegal, Sierra Leone, and Togo. Liberia was not considered due to paucity of data.

\section{Model specification}

The study employed the SVAR premised on Blanchard and Quah (1998) AD-AS framework extends the 2-variable VAR and 4-variable VAR model used in the literature to a 5-variable VAR model to examine the degree of symmetry and/or asymmetry of macroeconomic shocks among ECOWAS economies. Based on this analytical framework, countries will adopt a common currency if the shocks affecting the participating economies are positively correlated (symmetric) and vice versa.

The structural model is decomposed by specifying the five shocks world oil price (WOP), global GDP (GGDP), domestic real GDP (DRGDP), real effective exchange rate (REER) and inflation (INF), as follows:

$$
\begin{aligned}
& \triangle W O P_{t}=A_{11}(L) \varepsilon_{t}^{S *} \\
& \triangle G G D P_{t}=A_{21}(L) \varepsilon_{t}^{S *}+A_{22}(L) \varepsilon_{t}^{S *} \\
& \triangle D R G D P_{t}=A_{31}(L) \varepsilon_{t}^{S *}+A_{32}(L) \varepsilon_{t}^{S *}+A_{33}(L) \varepsilon_{t}^{S} \\
& \Delta R E E R_{t}=A_{41}(L) \varepsilon_{t}^{S *}+A_{42}(L) \varepsilon_{t}^{S *}+A_{43}(L) \varepsilon_{t}^{d}+A_{44}(L) \varepsilon_{t}^{m} \\
& \Delta I N F_{t}=A_{51}(L) \varepsilon_{t}^{S *}+A_{52}(L) \varepsilon_{t}^{S *}+A_{53}(L) \varepsilon_{t}^{S}+A_{54}(L) \varepsilon_{t}^{d}+A_{55}(L) \varepsilon_{t}^{m}
\end{aligned}
$$

The $5 \times 5$ matrix $\left(\mathrm{A}_{\mathrm{i}}\right)$ provides the impulse responses of endogenous variables to structural shocks. $\epsilon=\left[\epsilon_{t} W O P, \epsilon_{t} G G D P, \epsilon_{t} D R G D P, \epsilon_{t} R E E R, \epsilon_{t} I N F\right]$, comprising of external world supply shock $\left(\epsilon_{t} W O P, \epsilon_{t} G G D P\right)$ domestic supply shock $\left(\epsilon_{t} D R G D P\right)$, domestic demand shock $\left(\epsilon_{t} R E E R\right)$, and monetary shock $\left.\epsilon_{t} I N F\right)$, respectively and are assumed to be serially uncorrelated. The long run restrictions are as follows:

World oil price is considered to be strictly exogenously, implying that $A_{11}(L) \neq$ 0 , while $A_{12}(L)=A_{13}(L)=A_{14}(L)=A_{15}(L)=0$. Global real GDP strictly evolves exogenously implying that $A_{21}(L) \neq 0$ and $A_{22}(L) \neq 0$, while $A_{23}(L)=A_{24}(L)=A_{25}(L)=0$.

Domestic real GDP is affected exclusively by supply shocks in world oil prices and global real GDP. Thus, $\mathrm{A}_{31}(L) \neq 0, \mathrm{~A}_{32}(L) \neq 0, \mathrm{~A}_{33}(L) \neq 0$, while $\mathrm{A}_{34}(L)=\mathrm{A}_{35}(L)=0$.

Real effective exchange rate is assumed to be affected only by shocks from the world oil price, global output, domestic supply shocks and domestic demand shocks, $\mathrm{A}_{41}(L) \neq 0, \mathrm{~A}_{42}(L) \neq 0, \mathrm{~A}_{43}(L) \neq 0, \mathrm{~A}_{44}(L) \neq 0$, while $\mathrm{A}_{45}(L)=0$.

Lastly, domestic price is assumed to be strictly endogenous, meaning that prices are affected by shocks from the world oil price, in global GDP, domestic supply, 
demand shocks as well as monetary shocks. Thus, $\mathrm{A}_{51}(L) \neq 0, \mathrm{~A}_{52}(L) \neq 0, \mathrm{~A}_{53}(L) \neq 0$, $\mathrm{A}_{54}(L) \neq 0$ and $\mathrm{A}_{55}(L)=0$.

The new decomposed model with restrictions can be represented in the matrix form:

$$
\left[\begin{array}{c}
\Delta W O P_{t} \\
\Delta G G D P_{t} \\
\Delta D R G D P_{t} \\
\Delta R E E R_{t} \\
\Delta I N F_{t}
\end{array}\right]=\left[\begin{array}{ccccc}
A_{11}(L) & 0 & 0 & 0 & 0 \\
A_{21}(L) & A_{22}(L) & 0 & 0 & 0 \\
A_{31}(L) & A_{32}(L) & A_{33}(L) & 0 & 0 \\
A_{41}(L) & A_{42}(L) & A_{43}(L) & A_{44}(L) & 0 \\
A_{51}(L) & A_{52}(L) & A_{53}(L) & A_{54}(L) & A_{55}(L)
\end{array}\right]\left[\begin{array}{c}
\varepsilon_{t}^{S *} \\
\varepsilon_{t}^{S *} \\
\varepsilon_{t}^{S} \\
\varepsilon_{t}^{d} \\
\varepsilon_{t}^{m}
\end{array}\right] \ldots
$$

The long run restrictions have been imposed to identify the structural underlying shocks. World oil prices (WOP) and global GDP are exogenous to country-specific domestic shocks, while all domestic variables are affected by shocks in world oil prices and global GDP.

\section{PRESENTATION AND ANALYSIS OF RESULTS}

Before implementing the multivariate SVAR model, the variables were screened in order to avoid spurious regression and ascertain the order of integration (stationarity) of the series by employing the Augmented Dicky-Fuller (ADF), Phillips Perron tests and the correlogram approach ${ }^{1}$ (Appendix 1). The results indicate that the variables of all the countries except Seirra Leone and Senegal have unit roots at levels. But after differencing the series once, all the variables became stationary at various levels of significance. Both ADF and PP tests provide conflicting results for the global GDP of Sierra Leone and domestic price for Senegal. However, this was settled with the use of spectra analysis which shows that both variables are integrated of order one. All the results satisfy the diagnostic tests.

\section{Diagnostic tests}

Appendix 2 shows the optimal lag lengths and serial correlation LM tests for the different VAR models. The different optimal lag lengths were chosen in order to ensure that the estimations of the structural VAR are consistent. The result reveals that only the VAR estimates of Benin, Ghana, Sierra Leone and Togo are in conformity with the Akaike Information Criterion (AIC) and the Swartz Information Criterion (SIC) lag selection criteria. The estimated SVAR models for the rest of the countries exhibited serial correlation at their original lags and thus, the appropriate lag lengths were selected based on the absence of the serial correlation test as indicated on Table 2 The results of the serial correlation LM tests indicate that all the models at the chosen lags are free from serial correlation because the p-values in the brackets are greater than 0.05 . Hence, the models are robust at their chosen lags.

\section{Stability test}

The next important test that follows the serial correlation LM-test is the VAR stability test. The estimated VAR model is stable (stationary) if all roots have modulus

\footnotetext{
${ }^{1} \mathrm{ADF}$ test: $\Delta \mathrm{X}_{t}=a+b t+\rho X_{t-1}+\sum_{i=1}^{k} \Delta X_{t-i}+\mu_{t}: \Delta X_{t}$ is the first difference of the series $X, k$ is the lag order, $t$ is the time.

$P P$ test: $\quad \Delta \mathrm{X}_{t}=a+b X_{t-1}+c\left(t+\frac{T}{2}\right)+\mu_{t}: a, b$, and $c$ are the coefficients and $T$ is the total number of observations. Therefore, the $A D F$ and $P P$ unit root tests posits a null hypothesis $\beta=0$ versus an alternative hypothesis $\beta<0$, where the $A D F$ and $P P$ statistics is compared with the observed Mackinnon critical values.
} 
less than one and lie inside the unit circle (Agung, 2009). Certain results (such as impulse response standard errors) are not valid if the VAR is not stable, (Eviews Help Menu, version 9.5).

Appendix 3 presents the VAR stability test for ECOWAS in the study sample. The results show that all the roots of the VAR model have a modulus less than one. Thus, the estimated VAR models of all the ECOWAS countries under consideration fulfil the stability condition. All initial preliminary VAR diagnostics have been fulfilled which permits the study to proceed with further analyses.

\section{Identification and correlation of structural shocks}

The traditional OCA theory lays emphasis on the importance of symmetric shocks for countries contemplating to form a monetary. The decision criterion is that a positive and significant correlation indicates that the shocks are symmetric, while negative or not statistically significant implies that the shocks are asymmetric. The results of the correlations of both external and domestic supply shocks, demand and monetary shocks among the ECOWAS economies are analysed in the following subsections.

\section{Correlation of external supply shocks}

\section{World oil price}

Appendix 4 presents the correlation coefficients of supply shocks across ECOWAS countries, with respect to world oil prices from 1975-2015. The results indicate that the correlations of external supply shocks are positive and highly significant for all ECOWAS countries. This implies that all ECOWAS countries respond to changes in World oil prices in almost the same manner (symmetric). The reason for the high correlation is because the price of oil in the world market affects the economies of all countries in the ECOWAS region irrespective of whether they are oil producing countries or not. Thus, higher correlation of shocks from world oil prices will increase the benefits of forming a monetary union by ECOWAS countries.

\section{Global Gross Domestic Product}

Appendix 5 presents the correlation coefficients of external supply shocks across ECOWAS countries, with respect to global GDP from 1975-2015. The results indicate that the correlations of external supply shocks are positive and significant across ECOWAS countries except for few pairs of countries: Guinea Bissau-Cape Verde; Nigeria-Cape Verde, Senegal-Cape Verde; Senegal- Gambia; Togo-Nigeria; TogoSenegal. The positive correlations of external shocks across ECOWAS countries show that their economies' respond to global shock is similar. Chuku (2012) attributes this similarity in shocks to the primary export-oriented structure of most West African economies. Thus, higher correlations from an external source suggest more benefits to ECOWAS countries because the adoption of a common currency will greatly reduce bilateral exchange rate distortions brought about by external disturbances. However, the correlations coefficients of Sierra Leone are negative. This implies that Sierra Leone's response to global shocks is asymmetric to other ECOWAS countries.

External sources of disturbance greatly affect ECOWAS countries. That notwithstanding, the response to these disturbances in the region are similar, but for Sierra Leone that displays a different response pattern with respect to global GDP. The implication is that Sierra Leone may be worse-off in a monetary union based on these criteria. 


\section{Correlation of domestic supply shocks (Domestic real GDP (DGDP)}

Appendix 6 presents the correlation coefficients of domestic supply shocks across ECOWAS. Among the pairs of countries studied, 17 pairs have insignificant correlation coefficients while 17 pairs have negative coefficients, making a total of 34 pairs of countries that have uncorrelated domestic supply shocks. This implies that domestic supply shocks across ECOWAS countries are largely asymmetric. The degree of asymmetry is justified because of the differences in the core primary export commodities among ECOWAS countries. However, the remaining 57 pairs of countries display positive and significant correlations. In a nut shell, ECOWAS countries exhibit different responses to domestic supply shocks and therefore, require different adjustment policies.

\section{Domestic demand shocks}

Appendix 7 provides the correlation coefficients of demand shocks among ECOWAS countries. The responses to demand shocks across ECOWAS countries are different because out of the 91 pairs of countries examined, only 38 have significant symmetric correlations in domestic demand shocks, while the rest display asymmetric responses. The results are similar to the findings of Fielding and Shield (2001) for the CFA zone. Chuku (2012) attributed the prevalence of asymmetric correlation in demand shocks to the weak inter-demand relationships among ECOWAS economies.

\section{Monetary shocks}

Appendix 8 shows the correlation results of monetary shocks among ECOWAS countries. Out of the 91 pairs of countries investigated, only 25 pairs of the countries have symmetric correlations in monetary shocks. The symmetry of monetary shocks is significant among WAEMU countries, whereas WAMZ countries have an asymmetric correlation of monetary shocks. The symmetry of monetary shocks among the WAEMU countries is due to the fact they belong to an already existing monetary. Hence, the response to a common monetary policy is likely to be similar. The other 66 pairs of ECOWAS countries either display negative or insignificant correlations between monetary shocks; implying that the potentials for symmetric adjustments within the context of a monetary union may not feasible.

\section{Homogeneity of shocks}

A one-way ANOVA analysis is used to categorize the nature of the shocks (symmetric/asymmetric) across ECOWAS countries. It is informative to know whether these shocks are heterogeneous (implying that forming a monetary union is costly) or homogeneous (implying that implying that forming a monetary union is costly). The basic idea is that if the identified shocks among ECOWAS countries have the same mean, then the shocks are homogeneous, otherwise heterogeneous. Secondly, it is important to measure the extent of volatility of supply and demand shocks because of policy stabilization. This is because smaller shocks imply less reliance to stabilization policies such as nominal exchange rate adjustments thereby making regional economies better candidates for a monetary union (Sheik, 2012). The size of the shock is measured using the coefficient of variation (CV). A CV value of less than one implies homogeneity among sub groups, whereas a $\mathrm{CV}$ value of more than 1 signifies heterogeneity among sub groups suggesting that the degree of variability among them is wide (Fischer, 2000; Palmer \& Reid, 2001).

Table 1 shows a summary result of both the one-way ANOVA test and coefficient of variance test. 
Table 1. One-way ANOVA test and Coefficient of Variance

\begin{tabular}{|c|c|c|c|c|}
\hline \multirow{2}{*}{ Source of Disturbance } & \multicolumn{2}{|c|}{$\begin{array}{c}\text { One-way ANOVA } \\
\text { (F-test) }\end{array}$} & \multicolumn{2}{|c|}{$\begin{array}{c}\text { Coefficient of Variance } \\
\text { (Levene-test) }\end{array}$} \\
\hline & Value & p-value & Value & p-value \\
\hline World Oil Price Shock & 39.48 & 0.0000 & 4.33 & 0.0000 \\
\hline Global GDP Shock & 70.74 & 0.0000 & 3.22 & 0.0003 \\
\hline Domestic Supply Shock & 118.8 & 0.0000 & 3.02 & 0.0007 \\
\hline Demand Shock & 43.83 & 0.0000 & 6.8 & 0.0000 \\
\hline Monetary Shock & 103.46 & 0.0000 & 7.4 & 0.0000 \\
\hline
\end{tabular}

The probability values are zero, implying that the means of the supply, demand and monetary shocks differ across ECOWAS countries. Hence, the identified shocks are heterogeneous. Furthermore, the CV values are greater than 1 with the monetary shock having a relatively higher degree of variation from other shocks. This implies that policy responses will be different across ECOWAS countries; hence, the formation a monetary union in the region will be costly.

\section{Size of identified shocks}

Table 2 reports the absolute average sizes of both external and domestic shocks across ECOWAS economies. The different relative sizes of the shocks indicate whether the different stabilization policies will be synchronous or whether a common stabilization will address different macroeconomic disturbances across West Africa. This implies that a common stabilization policy will be rendered ineffective if the identified shocks are larger. The impulse response coefficients are used to evaluate the size of the shocks since it traces the effect of a one-unit shock in each of the five endogenous variables.

Table 2. Size of external and internal shocks $(* 100)$

\begin{tabular}{|c|c|c|c|c|c|c|}
\hline Country & $\begin{array}{c}\text { External } \\
\text { Supply Shock } \\
\text { (WOP) } \\
\end{array}$ & $\begin{array}{c}\text { External } \\
\text { Supply Shock } \\
\text { (GGDP) } \\
\end{array}$ & $\begin{array}{c}\text { Domestic } \\
\text { Supply Shock }\end{array}$ & $\begin{array}{c}\text { Average } \\
\text { Supply } \\
\text { Shock } \\
\end{array}$ & $\begin{array}{c}\text { Demand } \\
\text { Shock }\end{array}$ & $\begin{array}{c}\text { Monetary } \\
\text { Shock }\end{array}$ \\
\hline Benin & 0.0011 & 0.0001 & 0.0006 & 0.0018 & 0.0266 & 0.1355 \\
\hline Burkina Faso & 0.0003 & 0.0011 & 0.0040 & 0.0053 & 0.0478 & 0.2296 \\
\hline Cape Verde & 0.0020 & 0.0006 & 0.0004 & 0.0030 & 0.0468 & 0.1418 \\
\hline Cote D'Ivoire & 0.0012 & 0.0021 & 0.0027 & 0.0060 & 0.0939 & 0.0807 \\
\hline Gambia & 0.0013 & 0.0004 & 0.0017 & 0.0034 & 0.0048 & 0.0025 \\
\hline Ghana & 0.0004 & 0.0011 & 0.0244 & 0.0259 & 0.0223 & 0.0055 \\
\hline Guinea & 0.0015 & 0.0010 & 0.0101 & 0.0126 & 0.0062 & 0.0089 \\
\hline Guinea Bissau & 0.0021 & 0.0005 & 0.0036 & 0.0062 & 0.1885 & 0.2229 \\
\hline Mali & 0.0011 & 0.0009 & 0.0007 & 0.0028 & 0.0549 & 0.0530 \\
\hline Niger & 0.0009 & 0.0013 & 0.0001 & 0.0023 & 0.0732 & 0.0574 \\
\hline Nigeria & 0.0023 & 0.0024 & 0.0110 & 0.0156 & 0.0023 & 0.0169 \\
\hline Senegal & 0.0013 & 0.0005 & 0.0015 & 0.0034 & 0.2690 & 0.1828 \\
\hline Sierra Leone & 0.0061 & 0.0011 & 0.0017 & 0.0089 & 0.1216 & 0.1236 \\
\hline Togo & 0.0029 & 0.0014 & 0.0054 & 0.0096 & 0.2768 & 0.0867 \\
\hline Average & 0.0018 & 0.0010 & 0.0048 & & 0.0882 & 0.0963 \\
\hline
\end{tabular}

Among the various economies, Benin, Mali, Niger and Niger have the smallest size of supply shocks at $0.18 \%, 0.23 \%$ and $0.28 \%$ respectively, while Guinea, Nigeria, Togo and Sierra Leone have the largest sizes of 1.26\%, 1.56, 0.96 and $0.89 \%$ respectively. For the average demand shocks, Togo, Senegal, Guinea Bissau and Sierra Leone have the largest sizes of $27.68 \%, 26.9 \%, 18.55$ and $12.1 \%$, while Nigeria, Gambia and Guinea have the smallest sizes of $0.23 \%, 0.48 \%$ and $0.62 \%$ respectively. On average, the size of monetary shock is high for Guinea Bissau (22.29\%), Burkina Faso $(22.96 \%)$, Senegal $(12.36 \%)$ and Cape Verde $(14.18 \%)$ respectively, while 
Gambia (0.25\%), Ghana (0.54\%), Guinea (0.89\%) and Nigeria (1.69\%) respectively. The results indicate that the average supply shock cutting across ECOWAS appear to be smaller than the average demand and monetary shocks with values $0.76 \%, 8.8 \%$ and $9.6 \%$ respectively.

Comparatively the average sizes of the disturbances are larger than the already established sizes for other monetary regions. For example, the average supply sizes for the following: Americas (0.06\%), Western Europe (0.03\%), East Asia (0.032\%), SAARC $(0.023 \%)$. The average demand sizes of demand shocks from other regions are: Americas $(0.145 \%)$, Western Europe $(0.022 \%)$, East Asia $(0.44 \%)$ and SAAR $(0.037 \%)$ (see Chuku, 2012). Thus, the absolute relative sizes of the different shocks across West Africa are high, indicating that the fixed exchange rate as a common stabilization will not address the macroeconomic disturbances of respective ECOWAS economies.

\section{Discussion of results}

One of the key issues highlighted in the optimum currency area theory clearly spelt out by Mundell (1961) is that a group of countries opting for a monetary union should not be hit by asymmetric shocks. The findings of this study reveal that the responses to changes in external shocks by ECOAWS countries are symmetric. The findings are similar to that of Allegret Sand-Zantman (2007) for the case Mercosur countries.

Just like Addison et al. (2005); Houssa (2008); Chuku (2012) and Ekong and Onye (2012), the findings of this study reveal that the demand, supply, monetary and shocks are among ECOWAS countries are asymmetric. Studies similar to the above findings: Ramos and Suriach (2004); Frenkel and Nickel (2002); Broz (2008) and Marinas (2012). Ramos and Suriach (2004) found that the enlargement of the EMU would require a costly process because they have idiosyncratic shocks. Kar (2011) argued that shocks across EU countries are different due to low labor productivity, lack of competitiveness, illicit flow of capital etc. On the contrary, the asymmetry of shocks across ECOAWS is characterized by weak inter-demand relationships among ECOWAS economies, low immobility of factors of production, non-diversification of their economies etc.

Though the findings of Sato, Zhang and McAlee (2005); Ling (2001); Tang, (2006); Jeon and Zhang (2007) among others Huang and Guo (2006); Koh and Lee (2010) etc suggest that a fully-fledged currency union in East Asia is not necessary, they however established that smaller sub-groupings could possibly form a monetary union. Their findings are analogous to this study because only WAEMU sub-set economies displayed similar responses to economic shocks. Therefore, smaller sub-regional groupings tend to validate the OCA theory as also evidenced in the work (Bayoumi \& Eichengreen, 1994) who submitted that currency unions are only feasible among clusters of regional blocs in East Asia. Lastly, the sizes of the shocks are bigger and differ from that of other studies due to the time frame of the study as well as the inclusion of the oil price variable in the estimation model.

\section{CONCLUSIONS}

This study evaluated the preparedness of ECOWAS towards a single currency by analysing the degree of symmetry and sizes of the identified shocks across member countries. The analysis was situated within the framework of the OCA theory. The SVAR was employed on secondary data from 1975 to 2015 . The findings reveal that external supply shocks across ECOWAS countries are positive and symmetric except for Sierra Leone. This implies that the adoption of a single currency with a common 
stabilization policy by all ECOWAS countries with the exception of Sierra Leone will greatly reduce bilateral exchange rate distortions caused by external disturbances, hence making them fit for a monetary union. However, the sizes of the shocks vary (higher for smaller economies and lower for larger economies) which might become asymmetric in the long run.

Secondly, domestic supply, monetary and demand shocks are asymmetric implying that ECOWAS countries for now require different adjustment policies because the potentials for symmetric adjustments within the context of a monetary union are not feasible. Thirdly, the absolute relative sizes of the different shocks across ECOWAS countries are high and different in sizes. The different relative sizes of the shocks indicate that adopting the fixed exchange rate as a common stabilization policy will not address the macroeconomic disturbances of respective ECOWAS economies. The recommendations that ensue from the findings are as follows:

ECOWAS governments should search their beam light on policies that will facilitate the diversification of their exports. The birth and re-birth of new quality products predicated on diversification will increase the export capacity of respective economies, reduce the rate of import demand across West Africa and strengthen the weak inter-demand relationships among ECOWAS economies which will in turn reduce the variability of demand shocks across ECOWAS economies.

Since factor mobility is an important perquisite entry condition to forming a currency union, ECOWAS countries need to relax policies that restrain factor mobility, payment of high custom duties and transit charges, high tariffs and delay in the process of documentation and requirements for product registration. Also, the governments need to improve and expand the network infrastructure across the entire region. All these will encourage the fast flow of capital from stronger economies to weaker economies across the region making the entire region to adjust faster and evenly to shocks. Secondly, the regulatory laws guiding the labour markets across West Africa need to be harmonized and made flexible. This will encourage labour mobility, easy resolution of labour conflicts, provide incentives for higher labour participation and foster better working conditions.

Thirdly, ECOWAS governments need to strengthen the intra-regional trade links among member countries by re-enforcing the already existing trade Treaties, ensuring that all trade barriers across the region are abolished. All these will increase the trade volume of respective economies and fast-track the creation of the expected common market that will greatly minimize the degree of macroeconomic disturbances across West Africa. However, governments of ECOWAS countries need to enforce the laws that govern cross-border transactions and put stringent measures to deter illegal trade transactions of goods and services across the entire region. This is because illegal trade is highly associated with macroeconomic disturbance and policy inconsistency.

The of asymmetry and different sizes of shocks among ECOWAS underscores the need for ECOWAS governments to further shift the targeted date beyond 2020 to create ample time for member countries to get fully prepared. Most importantly, WAEMU sub-set economies display similarity in the identified shocks, implying that English speaking West Africa countries (WAMZ) should be compelled to first of all form a second monetary union in the region. This will make them to fully understand the dynamics of how a common stabilization policy can reduce the variability of macroeconomic disturbances among member countries and how a one-size-fit all exchange rate policy facilitates economic and trade activities. 


\section{REFERENCES}

Addison, E., Opoku-Afari, M., and Kinful, E., (2005). Terms of trade and real exchange rate shocks and implications for the West African Monetary Zone, Bank of Ghana Working Paper No. 12.

Al-Turki, F. (2007). Essays on optimum currency area, PhD. Thesis, Department of Economics, University of Oregon, USA.

Bayoumi, T, and Eichengreen, B. (1994). Macroeconomic Adjustment Under Bretton Woods and the Post-Breton-Woods Float: An Impulse-Response Analysis. The Economic Journal, 104 (425), 813-827.

Baxter, M. and King, G. (1999). Measuring Business Cycles: Approximate Band-Pass Filters For Economic Time Series. The Review of Economics and Statistics, MIT Press, vol. 8, No. 4, pp. 575-593.

Ben, A. (2009). Analysis of shocks affecting Europe: EMU and some Central and Eastern acceding countries. Panoeconomicus, 56(1), 21-38.

Ben-Arfa, N. (2012). Gulf Cooperation Council monetary union: Business cycle synchronization, shocks correlation. International Business and Economic Research Journal, pp. 137-166.

Blanchard, O. and Quah, D. (1989). The dynamic effects of aggregate demand and supply disturbances. American Economic Review. 79, 655-673.

Broz, T. (2005). The Theory of Optimum Currency Areas: A Literature Review. Privredna kretanja i ekonomska politika, 104, 53.

Buigut, S. and Valev, N. (2005). Is the Proposed East African Monetary Union an Optimal Currency Area? A Structural Vector Autoregression Analysis. World Development, Vol. 33, No. 12, pp. 260-267.

Chuku, C. (2012). The Proposed Eco: Should West Africa Proceed with a Common Currency? Paper presented at the Centre for the Study of African Economies (CSAE) 2012 Conference on "Economic Development in Africa" Oxford University, Oxford 18-20.

De Grauwe, P. (1992). German Monetary Unification. European Economic Review, Vol 36, No (32-33), pp. 445-453.

De Grauwe, P. (2005). Economics of Monetary Union, 6th edition. Oxford University Press.

Darvas, Zand Szapáry, G. (2008). Business Cycle Synchronization in the Enlarged EU. Open Economies Review, vol. 19, no. 1, pp. 1-19, 2008.

Ekong, C. and Onye, K. (2012). On the Feasibility of a Common Currency in West Africa: Evidence from a Multivariate Structural VAR. Journal of Economic Theory, Vol. 4, No. 4, pp: 120-131.

Frankel, J and Rose, K. (1998). The Endogeneity of the Optimum Currency Area Criteria. The Economic Journal, 108(449), 1009-1025.

Guo, F. (2005). Essays on East Asian capital markets: Integration and implications for economic activity. Unpublished PhD thesis, City University of New York, United States - New York.

Harvey, S. and Cushing, M. (2015). Is West African Monetary Zone (WAMZ) a common currency area? Review of Development Finance, Vol. 5, No. 1, pp. 5363.

Horvath, J. and Rátfai, A. (2004). Supply and demand shocks in accession countries to the Economic and Monetary Union. Journal of Comparative Economics, Vol. 32, No. 2, pp. 202-211. 
Houssa, R. (2008). Monetary union in West Africa and asymmetric shocks: A dynamic structural factor model approach. Journal of Development Economics, Vol. 85, pp: 319-347.

Jeon, B. and Zhang, H. (2007). A currency union or an exchange rate union: Evidence from Northeast Asia. Journal of Economic Integration, Vol. 22, No. 2, pp. 256287.

Ishiyama, Y. (1975). The Theory of Optimum Currency Areas: A Survey (La theorie des zones monetaires optimales: etude) (La teoria de las zonas monetarias optimas: Un examen). Staff Papers - International Monetary Fund, 22(2), 344383.

Karras, G. (2006). Is Africa an Optimum Currency Area? A Comparison of Macroeconomic Costs and Benefits. Journal of African Economies, Vo.16

Kenen, P. (1969). The optimum currency area: an eclectic view, Mundell, Robert/Swoboda. Monetary Problems of the International Economy. Chicago: University of Chicago Press, pp. 41-60.

Koh, M. and Lee, G. (2010). The Economic Feasibility of an Optimum Currency Area In East Asia. Available Online. [Assessed 01 July 2016]: https://www.ecu.edu.au/-data/assets/pdf-file/0009/201033/7.2-Grace-andKoh.pdf

Krugman, P. (1993). The hub effect: Or, threeness in interregional trade, in W. J. Ethier, E. Helpman and J. P. Neary, eds., Theory, Policy and Dynamics in International Trade, Cambridge University Press.

Ling, H. (2001). Optimum currency areas in East Asia: A structural VAR approach. ASEAN Economic Bulletin, Vol.18, No. 2, pp. 206-217.

Marinas. M, (2012). Testing the Asymmetry of Shocks with Euro Area. Theoretical and Applied Economics, Vol XIX, No. 1, pp. 5-20.

Mckinnon, R. (1963): Theory of Optimum Currency Area. American Economic Review, Vol. 53, N0.4, pp. 717-725.

Mundell, R. (1961). A Theory of Optimum Currency Areas. American Economic Review, 51, pp. 657- 665.

Ramos, R. and Suriach, J. (2004). Shocking aspects of European enlargement. Eastern European Economics, Vol. 42, No. 5, pp. 36-57.

Sato, K., Zhang, Z. and Allen, D. (2009). The suitability of a monetary union in East Asia: What does the cointegration approach tell? Journal of Mathematics and Computer in Simulation Archives, Vol. 79, Issue. 9, pp. 2927-2937.

Tang, H. (2006). An Asian Monetary Union? Centre for Applied Macroeconomic Analysis, Crawford School of Public Policy, The Australian National University.

Tavlas, G. (1993). The New Theory of Optimum Currency Areas. The World Economy Vol 16, No 6, pp 663-685.

Tsangarides, C. and Qureshi, M. (2008). Monetary union membership in West Africa: A cluster analysis. World Development, Vol 36, No 7, pp 1261-1279. 


\section{APPENDIX}

Appendix 1. Unit Root Test Result

Augmented Dickey Fuller (ADF) Test Phillips Perron (PP) Test

Trend and Intercept. Test Critical Values $1 \%=-4.2050 ; 5 \%=-3.5298 ; 10 \%=-3.1946$

\begin{tabular}{|c|c|c|c|c|c|}
\hline Series & Levels & $1^{\text {st }}$ Difference & Levels & $1^{\text {st }}$ Difference & Order \\
\hline \multicolumn{6}{|l|}{ Benin } \\
\hline WOP & -1.869 & -5.547 & -1.874 & -5.572 & (I) \\
\hline GGDP & -2.351 & -4.886 & -2.443 & -4.895 & (I) \\
\hline DGDP & -2.902 & -7.240 & -2.908 & -7.212 & (I) \\
\hline REER & -1.886 & -6.555 & -1.929 & -6.554 & (I) \\
\hline INF & -2.539 & -9.054 & -2.559 & -8.935 & (I) \\
\hline \multicolumn{6}{|c|}{ Cape Verde } \\
\hline DGDP & -1.471 & -4.211 & -1.966 & -4.699 & (I) \\
\hline REER & -1.349 & -5.291 & -1.345 & -5.339 & (I) \\
\hline INF & -3.171 & -7.716 & -3.177 & -7.547 & (I) \\
\hline \multicolumn{6}{|c|}{ Gambia } \\
\hline DGDP & -1.245 & -7.026 & -1.383 & -7.498 & (I) \\
\hline REER & -2.684 & -6.576 & -2.694 & -6.570 & (I) \\
\hline INF & -3.241 & -8.304 & -3.231 & -8.240 & (I) \\
\hline \multicolumn{6}{|l|}{ Guinea } \\
\hline DGDP & -1.410 & -8.477 & -1.419 & -8.105 & (I) \\
\hline REER & -2.221 & -8.735 & -2.223 & -5.944 & (I) \\
\hline INF & -2.878 & -7.727 & -2.888 & -7.727 & (I) \\
\hline \multicolumn{6}{|l|}{ Mali } \\
\hline DGDP & -3.045 & -4.592 & -3.045 & -7.646 & (I) \\
\hline REER & -2.059 & -7.235 & -2.068 & -7.233 & (I) \\
\hline INF & -3.322 & -6.832 & -11.232 & -7.727 & (I) \\
\hline \multicolumn{6}{|l|}{ Nigeria } \\
\hline DGDP & -1.215 & -4.687 & -1.267 & -4.687 & (I) \\
\hline REER & -2.696 & -4.803 & -2.917 & -4.813 & (I) \\
\hline INF & -3.359 & -6.515 & -3.424 & -6.860 & (I) \\
\hline \multicolumn{6}{|c|}{ Seirra Leone } \\
\hline DGDP & -2.410 & -3.481 & -4.015 & correlogram & (I) \\
\hline REER & -2.433 & -5.757 & -2.437 & -6.214 & (I) \\
\hline INF & -3.391 & -6.854 & -3.413 & 8.309 & (I) \\
\hline \multicolumn{6}{|c|}{ Burkina Faso } \\
\hline DGDP & -1.349 & -6.177 & -1.413 & -6.179 & (I) \\
\hline REER & -2.025 & -7.215 & -2.025 & -7.252 & (I) \\
\hline INF & -2.315 & -8.114 & -3.412 & -11.298 & (I) \\
\hline \multicolumn{6}{|c|}{ Cote D'Ivoire } \\
\hline DGDP & -2.011 & -4.904 & -2.262 & -4.974 & (I) \\
\hline REER & -2.579 & -6.546 & -2.590 & -6.546 & (I) \\
\hline INF & -3.134 & -0.723 & 3.151 & -8.208 & (I) \\
\hline \multicolumn{6}{|c|}{ GHANA } \\
\hline DGDP & -1.498 & -4.393 & -2.141 & -4.443 & (I) \\
\hline REER & -2.326 & -3.807 & -2.688 & -4.203 & (I) \\
\hline INF & -3.126 & -11.244 & -3.134 & -11.000 & (I) \\
\hline \multicolumn{6}{|c|}{ Guinea Bissau } \\
\hline DGDP & -3.049 & -8.294 & -3.092 & -8.250 & (I) \\
\hline REER & -1.887 & -4.177 & -1.887 & -5.247 & (I) \\
\hline INF & -2.275 & -2.174 & -2.787 & -9.405 & (I) \\
\hline \multicolumn{6}{|l|}{ Niger } \\
\hline DGDP & -0.386 & -6.043 & -0.465 & -6.049 & (I) \\
\hline REER & -1.668 & -6.553 & -1.677 & -6.540 & (I) \\
\hline INF & -3.212 & -8.449 & -3.132 & -8.248 & (I) \\
\hline \multicolumn{6}{|l|}{ Senegal } \\
\hline DGDP & -2.026 & -7.938 & -2.085 & -7.753 & (I) \\
\hline REER & -2.149 & -6.621 & -2.160 & -6.614 & (I) \\
\hline INF & -6.654 & Correlogram & -6.554 & correlogram & (I) \\
\hline \multicolumn{6}{|l|}{ Togo } \\
\hline DGDP & -1.607 & -5.324 & -1.634 & -5.325 & (I) \\
\hline REER & -1.932 & -7.288 & -1.941 & -7.284 & (I) \\
\hline INF & -3.415 & -6.464 & -3.422 & -8.855 & (I) \\
\hline
\end{tabular}

Source: Author's computation using Eviews 9.5 
Appendix 2. SVAR lag length selection criteria/serial correlationtest

\begin{tabular}{|c|c|c|}
\hline Country & Lag Length & LM - Test \\
\hline Benin & 1 & $21.34(0.6737)$ \\
\hline Burkina Faso & 1 & $26.54(0.6068)$ \\
\hline Cape verde & 2 & $7.89(0.99000)$ \\
\hline Cote D'Ivoire & 2 & $22.59(0.6014)$ \\
\hline Gambia & 2 & $34.06(0.1066)$ \\
\hline Guinea & 1 & $25.03(0.4609)$ \\
\hline Guinea Bissau & 1 & $26.2390 .3956)$ \\
\hline Ghana & 3 & $19.91(0.7515)$ \\
\hline Mali & 3 & $23.05(0.5673)$ \\
\hline Niger & 1 & $26.55(0.3785)$ \\
\hline Nigeria & 2 & $13.76(0.9657)$ \\
\hline Senegal & 2 & $26.37(0.3879)$ \\
\hline Sierra Leone & 3 & $22.98(0.6079)$ \\
\hline Togo & 1 & $35.09(0.0865)$ \\
\hline
\end{tabular}

(*) represent the probability Values of the LM test

Source: Author's computation using Eviews 9.5

Appendix 3. Eigen value stability test

\begin{tabular}{|c|c|c|c|c|c|c|c|}
\hline & Modulus & Eigen Value & Modulus & Eigen Value & Modulus & Eigen Value & Modulus \\
\hline Benin & & Guinea & & Ghana & & Sierra Leone & \\
\hline $0.554278+0.353482 i$ & 0.657399 & $-0.042733-0.754932 i$ & 0.75614 & $0.007801+0.711052 i$ & 0.7111 & $-0.016393-0.750291 i$ & 0.75047 \\
\hline $0.554278-0.353482 i$ & 0.657399 & $-0.042733+0.754932 i$ & 0.75614 & $0.007801-0.711052 i$ & 0.7111 & $-0.016393+0.750291 i$ & 0.75047 \\
\hline $0.119947+0.566748 \mathrm{i}$ & 0.579302 & $0.567346+0.311451 i$ & 0.64721 & 0.694142 & 0.6941 & $0.547701-0.416176 i$ & 0.68788 \\
\hline $0.119947-0.566748 i$ & 0.579302 & $0.567346-0.311451 i$ & 0.64721 & $-0.586702-0.160775 i$ & 0.6083 & $0.547701+0.416176 i$ & 0.68788 \\
\hline-0.539103 & 0.539103 & $-0.367462+0.488236 i$ & 0.61107 & $-0.586702+0.160775 i$ & 0.6083 & $0.336884-0.494706 i$ & 0.598519 \\
\hline$-0.202457+0.474957 i$ & 0.516307 & $-0.367462-0.488236 i$ & 0.61107 & $0.495932-0.276168 i$ & 0.5676 & $0.336884+0.494706 i$ & 0.598519 \\
\hline$-0.202457-0.474957 i$ & 0.516307 & $0.078410-0.563875 i$ & 0.5693 & $0.495932+0.276168 i$ & 0.5676 & -0.39503 & 0.39503 \\
\hline$-0.422600+0.135493 i$ & 0.44379 & $0.078410+0.563875 i$ & 0.5693 & $-0.063931+0.224422 i$ & 0.2334 & $-0.182078-0.340505 i$ & 0.38613 \\
\hline$-0.422600-0.135493 i$ & 0.44379 & -0.328337 & 0.32834 & $-0.063931-0.224422 i$ & 0.2334 & $-0.182078+0.340505 i$ & 0.38613 \\
\hline 0.0542 & 0.0542 & -0.242868 & 0.24287 & 0.202611 & 0.2026 & 0.234024 & 0.234024 \\
\hline Burkina Faso & & Guinea Bissau & & Togo & & Nigeria & \\
\hline$-0.343063-0.454031 i$ & 0.569067 & $-0.010830+0.631864 i$ & 0.63196 & $0.083682+0.720029 i$ & 0.7249 & $0.808062+0.308190 i$ & 0.864839 \\
\hline$-0.343063+0.454031 i$ & 0.569067 & $-0.010830-0.631864 i$ & 0.63196 & $0.083682-0.720029 i$ & 0.7249 & $0.808062-0.308190 \mathrm{i}$ & 0.864839 \\
\hline 0.519176 & 0.519176 & $-0.200146-0.576269 i$ & 0.61004 & $0.549376+0.261341 i$ & 0.6084 & $0.560399+0.607904 i$ & 0.826798 \\
\hline $0.065931-0.512600 \mathrm{i}$ & 0.516822 & $-0.200146+0.576269 i$ & 0.61004 & $0.549376-0.261341 i$ & 0.6084 & $0.560399-0.607904 i$ & 0.826798 \\
\hline $0.065931+0.512600 \mathrm{i}$ & 0.516822 & -0.599737 & 0.59974 & $-0.521351-0.123648 i$ & 0.5358 & $-0.189669+0.804581 i$ & 0.826635 \\
\hline $\begin{array}{c}-0.222273-0.458397 i \\
-0.222273+0.458397 i\end{array}$ & $\begin{array}{l}0.509444 \\
0.509444\end{array}$ & $\begin{array}{l}0.403724-0 \\
0.403724+0\end{array}$ & & $\begin{array}{l}-0.521351+ \\
-0.166271-\end{array}$ & & & \\
\hline $0.311860-0.391729 i$ & 0.500708 & -0.201655 & 0.20166 & $-0.166271+0.482588 i$ & 0.5104 & $-0.567353-0.567183 i$ & 0.802238 \\
\hline $0.311860+0.391729 i$ & 0.500708 & $0.024226+0.171096 \mathrm{i}$ & 0.1728 & $-0.006645+0.283191 i$ & 0.2833 & $0.255006+0.733190 i$ & 0.77627 \\
\hline-0.341224 & 0.341224 & $0.024226-0.171096 i$ & 0.1728 & $-0.006645-0.283191 i$ & 0.2833 & $0.255006-0.733190 \mathrm{i}$ & 0.77627 \\
\hline Cape verde & & Mali & & Gambia & & Senegal & \\
\hline$-0.693945+0.313852 i$ & 0.761618 & $-0.144745+0.773233 i$ & 0.78666 & $-0.136608+0.641655 i$ & 0.656 & $-0.379520-0.490034 i$ & 0.619813 \\
\hline$-0.693945-0.313852 i$ & 0.761618 & $-0.144745-0.773233 i$ & 0.78666 & $-0.136608-0.641655 i$ & 0.656 & $-0.379520+0.490034 i$ & 0.619813 \\
\hline $0.319485+0.656406 i$ & 0.730027 & $-0.432826+0.498445 i$ & 0.66014 & $-0.579897+0.247470 \mathrm{i}$ & 0.6305 & 0.609 & 0.609 \\
\hline $0.319485-0.656406 i$ & 0.730027 & $-0.432826-0.498445 i$ & 0.66014 & $-0.579897-0.247470 \mathrm{i}$ & 0.6305 & $0.158809+0.564269 i$ & 0.586191 \\
\hline 0.667121 & 0.667121 & $0.061592-0.462672 i$ & 0.46675 & $0.358816-0.424664 \mathrm{i}$ & 0.556 & $0.158809-0.564269 i$ & 0.586191 \\
\hline$-0.108838-0.613419 i$ & 0.623 & $0.061592+0.462672 i$ & 0.46675 & $0.358816+0.424664 i$ & 0.556 & $-0.039477-0.497978 i$ & 0.49954 \\
\hline$-0.108838+0.613419 i$ & 0.623 & $0.344943+0.261037 i$ & 0.43258 & $0.153256-0.365128 i$ & 0.396 & $-0.039477+0.497978 i$ & 0.49954 \\
\hline-0.612532 & 0.612532 & $0.344943-0.261037 i$ & 0.43258 & $0.153256+0.365128 i$ & 0.396 & -0.271949 & 0.271949 \\
\hline $0.232740-0.144067 i$ & 0.273721 & -0.36128 & 0.36128 & $0.019941+0.160729 i$ & 0.162 & $3770+0.09$ & 0.092542 \\
\hline $0.232740+0.144067 i$ & 0.273721 & -0.056964 & 0.05696 & $0.019941-0.160729 i$ & 0.162 & $-0.013770-0.091512 i$ & 0.092542 \\
\hline Cote D'Ivoire & & Niger & & & & & \\
\hline$-0.544820+0.462679 i$ & 0.714773 & $0.012491+0.686613 \mathrm{i}$ & 0.68673 & & & & \\
\hline$-0.544820-0.462679 i$ & 0.714773 & $0.012491-0.686613 i$ & 0.68673 & & & & \\
\hline $0.129163+0.632396 i$ & 0.645452 & $0.615408+0.165390 \mathrm{i}$ & 0.63725 & & & & \\
\hline $0.129163-0.632396 i$ & 0.645452 & $0.615408-0.165390 \mathrm{i}$ & 0.63725 & & & & \\
\hline $0.491089-0.227585 i$ & 0.541261 & $-0.418547-0.384687 i$ & 0.56848 & & & & \\
\hline $0.491089+0.227585 i$ & 0.541261 & $-0.418547+0.384687 i$ & 0.56848 & & & & \\
\hline$-0.112022+0.446895 i$ & 0.460721 & $-0.103397+0.461391 i$ & 0.47284 & & & & \\
\hline$-0.112022-0.446895 i$ & 0.460721 & $-0.103397-0.461391 i$ & 0.47284 & & & & \\
\hline 0.418008 & 0.418008 & -0.46545 & & & & & \\
\hline-0.20296 & 0.20296 & -0.214183 & 0.21418 & & & & \\
\hline
\end{tabular}

Source: Author's computation using Eviews 9.5 
Appendix 4. Correlations of external supply shocks (world oil price) 1975 to 2015

\begin{tabular}{|c|c|c|c|c|c|c|c|c|c|c|c|c|c|c|}
\hline & BENIN & BURKINA & CAPE & COTED & GAMBIA & GHANA & GUINEA & GBISSAU & NIGER & MALI & NIGERIA & SENEG & SIERRA & TOGO \\
\hline BENIN & 1.0000 & & & & & & & & & & & & & \\
\hline & $\cdots$ & & & & & & & & & & & & & \\
\hline BURKINA & 0.7273 & 1.0000 & & & & & & & & & & & & \\
\hline t-value & 2.9973 & $\cdots$ & & & & & & & & & & & & \\
\hline CAPE & 0.8797 & 0.9546 & 1.0000 & & & & & & & & & & & \\
\hline t-value & 5.2322 & 9.0655 & $\cdots$ & & & & & & & & & & & \\
\hline COTED & 0.9785 & 0.8467 & 0.9576 & 1.0000 & & & & & & & & & & \\
\hline t-value & 13.4303 & 4.5010 & 9.3971 & $\cdots-$ & & & & & & & & & & \\
\hline GAMBIA & 0.6435 & 0.9892 & 0.9192 & 0.7839 & 1.0000 & & & & & & & & & \\
\hline t-value & 2.3781 & 19.0855 & 6.6037 & 3.5715 & $\cdots$ & & & & & & & & & \\
\hline GHANA & 0.6532 & 0.9922 & 0.9200 & 0.7858 & 0.9889 & 1.0000 & & & & & & & & \\
\hline t-value & 2.4399 & 22.4804 & 6.6390 & 3.5933 & 18.7916 & $\cdots$ & & & & & & & & \\
\hline GUINEA & 0.7866 & 0.9622 & 0.9289 & 0.8703 & 0.9279 & 0.9528 & 1.0000 & & & & & & & \\
\hline t-value & 3.6030 & 9.9968 & 7.0953 & 4.9977 & 7.0416 & 8.8747 & $\cdots$ & & & & & & & \\
\hline GBISSAU & 0.9250 & 0.9270 & 0.9918 & 0.9832 & 0.8837 & 0.8803 & 0.9226 & 1.0000 & & & & & & \\
\hline t-value & 6.8879 & 6.9914 & 21.9386 & 15.2171 & 5.3392 & 5.2488 & 6.7664 & $-\cdots$ & & & & & & \\
\hline NIGER & 0.6085 & 0.9849 & 0.8927 & 0.7504 & 0.9949 & 0.9918 & 0.9358 & 0.8556 & 1.0000 & & & & & \\
\hline t-value & 2.1689 & 16.1099 & 5.6037 & 3.2113 & 27.8813 & 21.9451 & 7.5051 & 4.6744 & $-\cdots-$ & & & & & \\
\hline MALI & 0.6742 & 0.9285 & 0.9285 & 0.8073 & 0.9423 & 0.9115 & 0.8164 & 0.8895 & 0.9053 & 1.0000 & & & & \\
\hline t-value & 2.5823 & 7.0727 & 7.0741 & 3.8694 & 7.9577 & 6.2700 & 3.9982 & 5.5054 & 6.0280 & $\cdots-$ & & & & \\
\hline NIGERIA & 0.8309 & 0.7930 & 0.8062 & 0.8459 & 0.7282 & 0.7497 & 0.8822 & 0.8438 & 0.7429 & 0.5882 & 1.0000 & & & \\
\hline $\mathrm{t}$-value & 4.2242 & 3.6814 & 3.8545 & 4.4866 & 3.0051 & 3.2045 & 5.2986 & 4.4478 & 3.1388 & 2.0573 & $\cdots-$ & & & \\
\hline SENEG & 0.9668 & 0.8752 & 0.9614 & 0.9942 & 0.8123 & 0.8177 & 0.9037 & 0.9861 & 0.7877 & 0.8050 & 0.8853 & 1.0000 & & \\
\hline t-value & 10.6984 & 5.1167 & 9.8794 & 26.0952 & 3.9394 & 4.0175 & 5.9713 & 16.8090 & 3.6163 & 3.8378 & 5.3842 & $-\cdots$ & & \\
\hline SIERRA & 0.7791 & 0.9895 & 0.9587 & 0.8788 & 0.9639 & 0.9705 & 0.9679 & 0.9432 & 0.9626 & 0.8911 & 0.8549 & 0.9116 & 1.0000 & \\
\hline $\mathrm{t}$-value & 3.5151 & 19.3568 & 9.5298 & 5.2089 & 10.2438 & 11.3816 & 10.8949 & 8.0330 & 10.0541 & 5.5548 & 4.6611 & 6.2740 & $\cdots-$ & \\
\hline TOGO & 0.6521 & 0.9931 & 0.9258 & 0.7883 & 0.9935 & 0.9983 & 0.9396 & 0.8846 & 0.9919 & 0.9320 & 0.7321 & 0.8172 & 0.9695 & 1.0000 \\
\hline $\mathrm{t}$-value & 2.4329 & 23.9714 & 6.9272 & 3.6233 & 24.6694 & 48.2499 & 7.7637 & 5.3637 & 22.1215 & 7.2705 & 3.0402 & 4.0100 & 11.1904 & $\cdots$ \\
\hline
\end{tabular}

Correlation coefficients are in bold, while t-values are un-bold and the value of 2.0 and above indicates the significance of the coefficient at 5\%. Positive and statistically significant correlation coefficient indicates symmetry, while negative shows asymmetry.

Source: Author's computation using Eviews 9.5

Appendix 5. Correlations of external supply shocks (Global GDP) 1975 to 2015

\begin{tabular}{|c|c|c|c|c|c|c|c|c|c|c|c|c|c|c|}
\hline & BENIN & BURKINA & CAPEV & COTED & GAMBIA & GHANA & GUINEA & GUINEAB & MALI & NIGER & NIGERIA & SENEGAL & SIERRAL & TOGO \\
\hline \multirow[t]{2}{*}{ BENIN } & 1.0000 & & & & & & & & & & & & & \\
\hline & $\cdots$ & & & & & & & & & & & & & \\
\hline BURKINA & 0.9599 & 1.0000 & & & & & & & & & & & & \\
\hline t-value & 9.6879 & $\ldots-$. & & & & & & & & & & & & \\
\hline CAPEV & 0.7083 & 0.8184 & 1.0000 & & & & & & & & & & & \\
\hline t-value & 2.8381 & 4.0289 & $\cdots$ & & & & & & & & & & & \\
\hline COTED & 0.9603 & 0.9868 & 0.8702 & 1.0000 & & & & & & & & & & \\
\hline $\mathrm{t}$-value & 9.7410 & 17.2572 & 4.9960 & $-\cdots-\cdot$ & & & & & & & & & & \\
\hline GAMBIA & 0.8593 & 0.9538 & 0.9367 & 0.9638 & 1.0000 & & & & & & & & & \\
\hline t-value & 4.7520 & 8.9822 & 7.5694 & 10.2237 & $\ldots$ & & & & & & & & & \\
\hline GHANA & 0.9514 & 0.9808 & 0.7033 & 0.9455 & 0.8987 & 1.0000 & & & & & & & & \\
\hline t-value & 8.7428 & 14.2254 & 2.7982 & 8.2139 & 5.7970 & $\ldots--$ & & & & & & & & \\
\hline GUINEA & 0.9951 & 0.9520 & 0.7354 & 0.9613 & 0.8604 & 0.9272 & 1.0000 & & & & & & & \\
\hline t-value & 28.5382 & 8.7964 & 3.0698 & 9.8727 & 4.7761 & 7.0010 & $\cdots$ & & & & & & & \\
\hline GUINEAB & 0.9728 & 0.8797 & 0.5392 & 0.8716 & 0.7191 & 0.8942 & 0.9661 & 1.0000 & & & & & & \\
\hline t-value & 11.8800 & 5.2328 & 1.8107 & 5.0279 & 2.9273 & 5.6484 & 10.5804 & $\cdots$ & & & & & & \\
\hline MALI & 0.9667 & 0.9803 & 0.8529 & 0.9925 & 0.9481 & 0.9361 & 0.9729 & 0.8877 & 1.0000 & & & & & \\
\hline t-value & 10.6833 & 14.0289 & 4.6201 & 22.9519 & 8.4296 & 7.5246 & 11.9005 & 5.4532 & $\cdots$ & & & & & \\
\hline NIGER & 0.9835 & 0.9136 & 0.5749 & 0.8984 & 0.7631 & 0.9310 & 0.9719 & 0.9956 & 0.9088 & 1.0000 & & & & \\
\hline t-value & 15.3722 & 6.3543 & 1.9872 & 5.7857 & 3.3393 & 7.2120 & 11.6788 & 30.1065 & 6.1610 & $\cdots-.-$ & & & & \\
\hline NIGERIA & 0.7191 & 0.6904 & 0.3400 & 0.6195 & 0.5518 & 0.7206 & 0.7214 & 0.7443 & 0.6773 & 0.7469 & 1.0000 & & & \\
\hline t-value & 2.9267 & 2.6993 & 1.0224 & 2.2324 & 1.8716 & 2.9398 & 2.9462 & 3.1518 & 2.6042 & 3.1768 & $\cdots-$ & & & \\
\hline SENEGAL & 0.7596 & 0.7438 & 0.2540 & 0.6569 & 0.5713 & 0.8593 & 0.6993 & 0.7829 & 0.6470 & 0.8166 & 0.6883 & 1.0000 & & \\
\hline $\mathrm{t}$-value & 3.3030 & 3.1476 & 0.7427 & 2.4641 & 1.9686 & 4.7529 & 2.7667 & 3.5593 & 2.3998 & 4.0008 & 2.6840 & $\cdots$ & & \\
\hline SIERRAL & -0.7476 & -0.6175 & -0.1036 & -0.5679 & -0.3706 & -0.7183 & -0.7048 & -0.8529 & -0.5649 & -0.8478 & -0.5580 & -0.8656 & 1.0000 & \\
\hline t-value & -3.1842 & -2.2205 & -0.2947 & -1.9513 & -1.1285 & -2.9203 & -2.8104 & -4.6202 & -1.9363 & -4.5226 & -1.9021 & -4.8901 & $\cdots$ & \\
\hline TOGO & 0.8310 & 0.8934 & 0.9782 & 0.9425 & 0.9560 & 0.7937 & 0.8553 & 0.6969 & 0.9325 & 0.7226 & 0.4448 & 0.3758 & -0.2871 & 1.0000 \\
\hline t-value & 4.2258 & 5.6242 & 13.3161 & 7.9781 & 9.2115 & 3.6901 & 4.6690 & 2.7483 & 7.3021 & 2.9565 & 1.4047 & 1.1471 & -0.8477 & $\cdots$ \\
\hline
\end{tabular}

Source: Author's computation using Eviews 9.5 
Appendix 6. Correlations of domestic supply shocks (GDP), 1975 to 2015

\begin{tabular}{|c|c|c|c|c|c|c|c|c|c|c|c|c|c|c|}
\hline & BENIN & BURKINA & CAPEV & COTED & GAMBIA & GHANA & GUINEA & GUINEAB & MALI & NIGER & NIGERIA & SENEGAL & SIERRAL & TOGO \\
\hline BENIN & 1 & & & & & & & & & & & & & \\
\hline & $\cdots-\cdot$ & & & & & & & & & & & & & \\
\hline BURKINA & \begin{tabular}{|l|}
0.6409 \\
\end{tabular} & 1 & & & & & & & & & & & & \\
\hline t-value & \begin{tabular}{|l|l|}
2.36151 \\
\end{tabular} & $\cdots-$ & & & & & & & & & & & & \\
\hline CAPEV & \begin{tabular}{|l|l|} 
& -0.783 \\
\end{tabular} & -0.951837 & 1 & & & & & & & & & & & \\
\hline t-value & \begin{tabular}{|l|l|} 
& -3.56089 \\
\end{tabular} & -8.780689 & $\cdots$ & & & & & & & & & & & \\
\hline COTED & 0.9842 & 0.56907 & -0.6995 & 1 & & & & & & & & & & \\
\hline tvalue & \begin{tabular}{|l|l}
15.72263 \\
\end{tabular} & 1.957431 & -2.768757 & $\ldots-$ & & & & & & & & & & \\
\hline GAMBIA & \begin{tabular}{|l|l|}
0.7207 \\
\end{tabular} & 0.978952 & -0.933 & 0.67952 & 1 & & & & & & & & & \\
\hline t-value & 2.940688 & 13.566691 & -7.333502 & 2.61973 & $\cdots$ & & & & & & & & & \\
\hline GHANA & \begin{tabular}{|l|l|}
0.4699 \\
\end{tabular} & 0.834041 & -0.6711 & 0.46617 & 0.87853 & 1 & & & & & & & & \\
\hline tvalue & 1.505761 & 4.275897 & -2.560014 & 1.490379 & 5.201927 & $\cdots$ & & & & & & & & \\
\hline GUINEA & \begin{tabular}{|l|l|} 
& 0.7318 \\
\end{tabular} & 0.986916 & -0.9766 & 0.65376 & 0.96943 & 0.79562 & 1 & & & & & & & \\
\hline t-value & \begin{tabular}{|l|l|}
.036854 \\
\end{tabular} & 17.31275 & -12.85361 & 2.443631 & 11.17516 & 3.714749 & $\cdots-$ & & & & & & & \\
\hline GUINEAB & -0.967 & -0.432121 & 0.62659 & -0.9635 & -0.52188 & -0.2469 & -0.54598 & 1 & & & & & & \\
\hline t-value & -10.71 & -1.35529 & 2.27401 & -10.17895 & -1.73043 & $\begin{array}{l}-0.720534 \\
\end{array}$ & -1.84324 & $\cdots-\cdot$ & & & & & & \\
\hline MALI & \begin{tabular}{|l|l|}
0.7462 \\
\end{tabular} & 0.866901 & -0.8055 & 0.74317 & 0.94114 & 0.93129 & 0.8697 & -0.566377 & 1 & & & & & \\
\hline tvalue & \begin{tabular}{|l|l|}
3.170505 \\
\end{tabular} & 4.918874 & -3.844101 & 3.141534 & 7.875309 & 7.231024 & 4.983788 & -1.943778 & $\cdots-$. & & & & & \\
\hline NIGER & 0.915 & 0.823068 & -0.8586 & 0.90294 & 0.90446 & 0.764 & 0.86307 & -0.790476 & 0.9441 & 1 & & & & \\
\hline t-value & \begin{tabular}{|ll}
6.412984 \\
\end{tabular} & 4.098985 & -4.737884 & 5.942387 & 5.997407 & 3.349119 & 4.833144 & -3.650331 & 8.099313 & $\ldots-$ & & & & \\
\hline NIGERIA & \begin{tabular}{|l|}
0.9724 \\
\end{tabular} & 0.684648 & -0.7759 & 0.98286 & 0.78924 & 0.59431 & 0.74665 & -0.908349 & 0.8377 & 0.9602 & 1 & & & \\
\hline t-value & \begin{tabular}{|l|l|}
11.78937 \\
\end{tabular} & 2.656808 & -3.478245 & 15.08086 & 3.635129 & 2.090117 & 3.174661 & -6.143297 & 4.339003 & 9.723467 & $-\cdots-$ & & & \\
\hline SENEGAL & 0.885 & 0.888482 & -0.9058 & 0.8682 & 0.95302 & 0.79234 & 0.91366 & -0.741051 & 0.9462 & 0.9834 & 0.937819 & 1 & & \\
\hline t-value & \begin{tabular}{|l|l|}
5.376548 \\
\end{tabular} & 5.476025 & -6.047488 & 4.948676 & 8.898653 & 3.673407 & 6.357536 & -3.121626 & 8.270008 & 15.34711 & 7.641483 & $\cdots$ & & \\
\hline SIERRAL & \begin{tabular}{|l|}
0.6717 \\
\end{tabular} & 0.311269 & -0.3065 & 0.75074 & 0.47637 & 0.59744 & 0.36577 & -0.636499 & 0.7314 & 0.731 & 0.746475 & 0.642903 & 1 & \\
\hline tvalue & 2.564797 & 0.926426 & -0.910814 & 3.214365 & 1.532407 & 2.107203 & 1.111594 & -2.334169 & 3.033292 & 3.0304 & 3.172986 & 2.374057 & $\cdots-$ & \\
\hline TOGO & \begin{tabular}{|l|}
0.9637 \\
\end{tabular} & 0.443217 & -0.6462 & 0.94914 & 0.52012 & 0.22199 & 0.55922 & -0.997384 & 0.5438 & 0.777 & 0.893261 & 0.732019 & 0.58472 & 1 \\
\hline t-value & 10.2025 & 1.39847 & -2.395114 & 8.525989 & 1.722421 & 0.643933 & 1.907907 & -39.02583 & 1.83284 & 3.491043 & 5.620264 & 3.039058 & 2.038664 & \\
\hline
\end{tabular}

Source: Author's computation using Eviews 9.5

Appendix 7. Correlations of demand shocks (domestic price), 1975 to 2015

BENIN BURKINA CAPEV COTED GAMBIA GHANA GUINEA GUINEAB MALI NIGER NIGERIA SENEGAL SIERRAL TOGO

\begin{tabular}{|c|c|c|c|c|c|c|c|c|c|c|c|c|c|c|}
\hline BENIN & 1 & & & & & & & & & & & & & \\
\hline & $\cdots-$ & & & & & & & & & & & & & \\
\hline BURKINAF & 0.4259 & 1 & & & & & & & & & & & & \\
\hline t-value & 1.331239 & $\cdots-$. & & & & & & & & & & & & \\
\hline CAPEV & -0.441 & -0.74548 & 1 & & & & & & & & & & & \\
\hline t-value & -1.38887 & -3.163461 & $\ldots$ & & & & & & & & & & & \\
\hline COTED & 0.2045 & 0.5778 & -0.1141 & 1 & & & & & & & & & & \\
\hline t-value & 0.59102 & 2.002336 & -0.32484 & $\cdots-$ & & & & & & & & & & \\
\hline GAMBIA & 0.8834 & 0.408669 & -0.2958 & 0.55708 & 1 & & & & & & & & & \\
\hline t-value & 5.333044 & 1.266477 & -0.875975 & 1.89734 & $\cdots-$ & & & & & & & & & \\
\hline GHANA & 0.5187 & 0.96293 & -0.852 & 0.36727 & 0.390198 & 1 & & & & & & & & \\
\hline t-value & 1.71581 & 10.09668 & -4.603416 & 1.11683 & 1.198663 & $\cdots$ & & & & & & & & \\
\hline GUINEA & 0.1283 & 0.848495 & -0.3657 & 0.85367 & 0.330098 & 0.67456 & 1 & & & & & & & \\
\hline t-value & 0.365817 & 4.534937 & -1.111218 & 4.636173 & 0.989102 & 2.584503 & $\cdots-$ & & & & & & & \\
\hline GUINEAB & 0.2719 & 0.876289 & -0.4329 & 0.87829 & 0.472605 & 0.71822 & 0.986548 & 1 & & & & & & \\
\hline t-value & 0.799257 & 5.144435 & -1.358228 & 5.195669 & 1.516812 & 2.919476 & 17.06962 & $\cdots-$ & & & & & & \\
\hline MALI & 0.546 & 0.915107 & -0.8009 & 0.24341 & 0.340895 & 0.98027 & 0.583313 & 0.621934 & 1 & & & & & \\
\hline t-value & 1.843189 & 6.419252 & -3.782827 & 0.70983 & 1.025629 & 14.02746 & 2.031226 & 2.24641 & 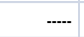 & & & & & \\
\hline NIGER & 0.3939 & 0.968678 & -0.6324 & 0.76172 & 0.490721 & 0.87536 & 0.932337 & 0.962016 & 0.797 & 1 & & & & \\
\hline t-value & 1.212247 & 11.03347 & -2.309133 & 3.32528 & 1.592956 & 5.121171 & 7.292929 & 9.967192 & 3.732348 & $\ldots$ & & & & \\
\hline NIGERIA & 0.3972 & 0.582271 & -0.2343 & 0.94921 & 0.721487 & 0.42393 & 0.752807 & 0.818254 & 0.2946 & 0.7519 & 1 & & & \\
\hline t-value & 1.224127 & 2.025732 & -0.68181 & 8.53257 & 2.947128 & 1.323892 & 3.234769 & 4.025996 & 0.871808 & 3.225874 & $\cdots$ & & & \\
\hline SENEGAL & 0.5923 & 0.978334 & -0.7809 & 0.57634 & 0.571357 & 0.96324 & 0.783415 & 0.843879 & 0.9147 & 0.9508 & 0.630047 & 1 & & \\
\hline t-value & 2.079349 & 13.36569 & -3.535451 & 1.994741 & 1.969099 & 10.14106 & 3.565305 & 4.448648 & 6.402007 & 8.683291 & 2.2948 & $\cdots$ & & \\
\hline SIERRAL & -0.102 & 0.281825 & 0.0466 & 0.90043 & 0.3498 & 0.05362 & 0.661233 & 0.666917 & -0.111 & 0.5026 & 0.84959 & 0.266438 & 1 & \\
\hline t-value & -0.28911 & 0.830796 & 0.131862 & 5.854828 & 1.056103 & 0.151891 & 2.493065 & 2.531533 & -0.31557 & 1.64436 & 4.555937 & 0.781864 & $\cdots-$ & \\
\hline TOGO & 0.5411 & 0.976795 & -0.8337 & 0.44705 & 0.450709 & 0.99571 & 0.71957 & 0.768466 & 0.9649 & 0.9106 & 0.504699 & 0.983025 & 0.134763 & 1 \\
\hline t-value & 1.820017 & 12.89954 & -4.269404 & 1.413546 & 1.428071 & 30.4486 & 2.930862 & 3.396757 & 10.39589 & 6.230975 & 1.653551 & 15.15432 & 0.384677 & $\cdots-$. \\
\hline
\end{tabular}

Source: Author's computation using Eviews 9.5 
Appendix 8. Correlations of monetary shocks (REER), 1975 to 2015

BENIN BURKINA CAPEV COTED GAMBIA GUINEA GHANA GUINEAB MALI NIGER NIGERIA SENEGAL SIERRAL TOGO

\begin{tabular}{|c|c|c|c|c|c|c|c|c|c|c|c|c|c|c|}
\hline BENIN & 1 & & & & & & & & & & & & & \\
\hline & $\cdots$ & & & & & & & & & & & & & \\
\hline BURKINA & -0.335 & 1 & & & & & & & & & & & & \\
\hline tvalue & -1.00529 & $\cdots-$. & & & & & & & & & & & & \\
\hline CAPEV & -0.086 & -0.897662 & 1 & & & & & & & & & & & \\
\hline tvalue & -0.24332 & -5.761431 & $\cdots$ & & & & & & & & & & & \\
\hline COTED & 0.7685 & -0.834466 & 0.51593 & 1 & & & & & & & & & & \\
\hline t-value & 3.396628 & -4.283065 & 1.703496 & $\ldots$ & & & & & & & & & & \\
\hline GAMBIA & 0.7165 & -0.639715 & 0.27834 & 0.85306 & 1 & & & & & & & & & \\
\hline t-value & 2.904711 & -2.354096 & 0.819648 & 4.623916 & $\cdots-$ & & & & & & & & & \\
\hline GUINEA & 0.202 & -0.965862 & 0.88978 & 0.75248 & 0.67264 & 1 & & & & & & & & \\
\hline tvalue & 0.583482 & -10.54541 & 5.51429 & 3.231531 & 2.571094 & $\ldots$ & & & & & & & & \\
\hline GHANA & 0.6015 & -0.740293 & 0.44054 & 0.82478 & 0.9608 & 0.786387 & 1 & & & & & & & \\
\hline t-value & 2.129681 & -3.11455 & 1.387996 & 4.125594 & 9.801706 & 3.600641 & $\cdots$ & & & & & & & \\
\hline GUINEAB & -0.915 & 0.244899 & 0.20099 & -0.69161 & -0.84429 & -0.210256 & -0.72668 & 1 & & & & & & \\
\hline tvalue & -6.40845 & 0.714434 & 0.58034 & -2.708375 & -4.456211 & -0.60829 & -2.991893 & $\cdots$ & & & & & & \\
\hline MALI & -0.333 & 0.946562 & -0.8011 & -0.84267 & -0.76884 & -0.970971 & -0.8188 & 0.347759 & 1 & & & & & \\
\hline t-value & -0.99941 & 8.30107 & -3.786343 & -4.42662 & -3.400804 & -11.48134 & -4.034141 & 1.049092 & $\cdots$ & & & & & \\
\hline NIGER & -0.387 & 0.976911 & -0.8222 & -0.88244 & -0.74518 & -0.967155 & -0.804932 & 0.354467 & 0.9877 & 1 & & & & \\
\hline t-value & -1.18864 & 12.93303 & -4.085873 & -5.305544 & -3.160623 & -10.76185 & -3.836902 & 1.072205 & 17.88836 & $\cdots-$ & & & & \\
\hline NIGERIA & -0.365 & -0.245627 & 0.51617 & -0.11064 & -0.54036 & 0.120067 & -0.374888 & 0.653661 & 0.0289 & -0.075 & 1 & & & \\
\hline tvalue & -1.10724 & -0.716695 & 1.704597 & -0.314861 & -1.816394 & 0.342074 & -1.143757 & 2.442998 & 0.081647 & -0.21338 & $\cdots$ & & & \\
\hline SENEGAL & -0.708 & 0.8303 & -0.5127 & -0.9567 & -0.95131 & -0.814022 & -0.949299 & 0.731582 & 0.8846 & 0.8918 & 0.269984 & 1 & & \\
\hline tvalue & -2.83793 & 4.213845 & -1.68913 & -9.296617 & -8.729785 & -3.963958 & -8.540838 & 3.035152 & 5.364164 & 5.575655 & 0.793082 & $\ldots$ & & \\
\hline SIERRAL & 0.6784 & -0.912735 & 0.64254 & 0.97369 & 0.85008 & 0.853225 & 0.879022 & -0.613619 & -0.896 & -0.932 & -0.039648 & -0.970308 & 1 & \\
\hline tvalue & 2.611853 & -6.318899 & 2.371782 & 12.086 & 4.565428 & 4.627196 & 5.214643 & -2.198041 & -5.71876 & -7.25197 & -0.11223 & -11.34674 & $\cdots-$ & \\
\hline TOGO & 0.8437 & -0.783215 & 0.43942 & 0.98717 & 0.85835 & 0.687201 & 0.829495 & -0.757194 & -0.773 & -0.82 & -0.142678 & -0.949201 & 0.963918 & 1 \\
\hline tvalue & 4.446076 & -3.562952 & 1.383611 & 17.48487 & 4.731863 & 2.67555 & 4.200735 & -3.278784 & -3.44827 & -4.04982 & -0.407727 & -8.531886 & 10.24184 & $\ldots .-$ \\
\hline
\end{tabular}

Source: Author's computation using Eviews 9.5 